\title{
TEACHER'S EFFORTS TO INCREASE MOTIVATION OF STUDENTS' SPIRI- TUAL AND SOCIAL ATTITUDES IN SMAN 1 SITUBONDO
}

\begin{abstract}
:
Oleh: Research that was done in SMAN 1 Situbondo has aim to describe comprehensively Mohammad Firmansyah the teacher's efforts of Islamic religion education to enhance student's spiritual and Abdul Muiz social attitude. This research using qualitative research metodologhy and data collection technique by observation, interview, documentation. The data was analyzed by data Email: moh.firsya95@gmail.com mu082301583008@gmail.com

Sekolah Tinggi Ilmu Syariah (STIS) Nurul Qarnain Jember reduction, display, as well as taking the result and verification technique. This research on the teacher's efforts of Islamic religion education to enhance student's spiritual and social attitude produced several findings are supervise student regularly, establish spiritual and social attitude through emotional quotient, giving assessment. Moreover avoid threat, sanctions, and bad comentar too. Using variety method, increase desire and interest more better, creating a condusive evironmental scene.
\end{abstract}

Universitas Ibrahimy Situbondo

Keywords: Spiritual Attitude, Social Attitude, Teacher's Efforts.

\section{PENDAHULUAN}

\section{Konteks Penelitian}

Sebagaimana tertuang dalam UndangUndang Republik Indonesia Nomor 20 Tahun 2003 tentang Sistem Pendidikan Nasional, tujuan pendidikan nasional tidak hanya berorientasi pada pengembangan aspek kognitif semata, melainkan pendidikan nasional tersebut juga bertujuan untuk mengembangkan dua aspek lainnya yaitu aspek afektif dan aspek psikomotorik. Dalam UndangUndang tersebut dinyatakan,

"Pendidikan nasional berfungsi mengembangkan kemampuan dan membentuk watak serta peradaban bangsa yang bermartabat dalam rangka mencerdaskan kebidupan bangsa, bertujuan untuk. berkembangnya potensi peserta didik agar menjadi manusia yang beriman dan bertakwa kepada Tuhan Yang Maha Esa, berakblak mulia, sehat, berilmu, cakap, kreatif, mandiri, dan menjadi warga negara yang demokratis serta bertanggungjawab."

Dalam Undang-Undang di atas dinyatakan secara eksplisit tentang keimanan dan ketakwaan kepada Tuhan Yang Maha Esa serta akhlak mulia menduduki posisi pertama dalam tujuan pendidikan nasional. Oleh karenanya, tujuan pendidikan Islam dibagi menjadi tujuan pendidikan ruhani, tujuan pendidikan sosial, tujuan pendidikan akal, dan tujuan pendidikan jasmani. ${ }^{1}$

Telah kita ketahui, bahwa iklim pendidikan di Indonesia ini bisa dibilang masih kurang kondusif. Terbukti dengan adanya berbagai permasalah dalam berbagai lini bidang pendidikan. Dalam tatatan grassroot, hal tersebut juga menimbulkan bias masalah sosial, seperti tawuran antar pelajar, premanisme, geng motor, banyak pelajar yang hamil di luar nikah, dan lain-lain.

Apa yang salah dengan pendidikan kita? Dalam konteks kekinian, ada indikasi yang menunjukkan bahwa pendidikan secara substansial telah kehilangan ruhnya. Hal ini ditunjukkan dengan adanya ketidakseimbangan dalam proporsi pengajaran yang diberikan. Pendidikan lebih cenderung menekankan aspek kognitif peserta didik dan mengabaikan aspek

\footnotetext{
${ }^{1}$ Abdurrahman Saleh Abdullah, Teori-teori Pendidikan Berdasarkan al-Qur'an, (Jakarta: PT. Rineka Cipta, 2007), 137.
} 
spiritualitas dan emosional mereka. ${ }^{2}$ Hal ini tidak lain karena kita lebih terfokus pada konsep pendidikan yang dikembangkan oleh Bloom dan kawan-kawan, itupun tidak mengembangkan secara maksimal, tetapi hanya pada ranah kognitif tingkat rendah.

Sejak tahun 1998, UNESCO telah menggunakan dua basis landasan untuk merevolusi serta menyempurnakan iklim pendidikan: pertama; pendidikan harus diletakkan pada empat pilar yaitu belajar mengetahui (learning to know), belajar melakukan (learning to do), belajar hidup dalam kebersamaan (learning to live together), dan belajar menjadi diri sendiri (learning to be); kedua, belajar seumur hidup (live long learning). Kultur yang demikian harus dikembangkan dalam pendidikan saat ini, karena pada akhirnya aspek kultural dan kehidupan manusia, terutama yang berkaitan dengan pendidikan nilai dan sikap lebih penting dari pertumbuhan ekonomi. Pendidikan nilai dan sikap, yang sekarang lebih dikenal dengan istilah pendidikan karakter merupakan upaya untuk membantu perkembangan jiwa anak didik secara lahir dan batin. ${ }^{3}$

Dari problem tersebut, akhirnya pemerintah mengambil jalan solutif dengan gebrakan terbarunya menata ulang kurikulum agar sesuai dengan kebutuhan pendidikan di dunia nyata yang telah diterapkan selama kurang lebih 2 tahun, yaitu Kurikulum 2013. Kelebihan Kurikulum 2013 daripada kurikulum sebelum-sebelumnya, kurikulum baru ini cenderung menekankan pada keseimbangan tiga domain pendidikan. Apabila pada kurikulum sebelumnya domain kognitif menempati urutan wahid, maka pada Kurikulum 2013 ini menyeimbangkannya dengan penekanan lebih pada aspek skill dan karakter (psikomotorik dan afektif). Bahkan, bisa dibilang domain afektif menempati urutan teratas, yang terwujud dalam KI.1 (spiritual) dan KI.2 (sosial), khususnya untuk mata pelajaran Pendidikan Agama Islam dan Budi Pekerti.

Guru sebagai salah satu komponen dari sistem pendidikan mempunyai peranan sangat penting dan strategis dalam upaya membentuk watak bangsa ini melalui kepribadian dan nilai-nilai

\footnotetext{
${ }^{2}$ Imron Fauzi, Manajemen Pendidikan ala Rasulullah, (Jogjakarta: Ar-Ruzz Media, 2012), 21.

3 E. Mulyasa, Pengembangan dan Implementasi Kurikulum 2013, (Bandung: PT Remaja Rosdakarya, 2014), 2-3.
}

yang diinginkan. Dipandang dari dimensi penanaman nilai positif dalam pendidikan, peranan guru dalam masyarakat Indonesia tetap dominan sekalipun berkembangnya teknologi yang bisa dimanfaatkan dalam pembelajaran. ${ }^{4} \mathrm{Hal}$ ini pun menunjukkan betapa guru memiliki peranan sangat penting dalam dunia pendidikan, karena guru selain mengajarkan pengetahuan juga menanamkan sifat mental peserta didik yang menyangkut aspek-aspek spiritualitas dan sosial, yang tidak bisa diwakili oleh mesin canggih manapun.

Tentunya, untuk meraih hasil maksimal dari dimensi pendidikan ini, guru sebagai pendidik harus memiliki kemampuan dan kapabilitas yang memadai, yang dalam dunia pendidikan disebut dengan kompetensi guru, dan guru yang memiliki kompetensi tersebut disebut guru profesional. Hal ini didasarkan PP Nomor 17 Tahun 2007 tentang guru, dinyatakan bahwa kompetensi yang harus dimiliki guru meliputi kompetensi pedagogik, kompetensi kepribadian, kompetensi sosial dan kompetensi profesional. $^{5}$

SMAN 1 Situbondo merupakan salah satu lembaga pendidikan yang menjadi acuan dari lembaga-lembaga lainnya dalam segala hal, baik dalam hal penerapan kurikulumnya, kegiatan sekolah serta kelengkapan sarana dan prasana. Sehingga alasan itu juga yang menjadikan SMAN 1 Situbondo harus dibangun dan terletak di jantung kota Santri. Santri adalah para murid yang belajar di pesantren, di sisi lain pesantren adalah tempat para santri belajar agama. ${ }^{6}$

Namun begitu, meski SMAN 1 Situbondo terletak di jantung kota serta menjadi sekolah favorit terutama bagi anak kota, SMASa (sebutan akrab SMAN 1 Situbondo) tidak serta merta mengabaikan pendidikan moral dan sikap sosial yang harus dimiliki oleh semua peserta didik.

Hal ini terbukti ketika pelaksanaan PPL (Praktik Pengalaman Lapangan) di SMAN 1

\footnotetext{
${ }^{4}$ Buchari Alma, Dkk, Guru Profesional, (Bandung: Alfabeta, 2014), 132

${ }^{5}$ Buchari Alma, Dkk, Guru Profesional, (Bandung: Alfabeta, 2014), 132

${ }^{6}$ Moh. Nawafil dan Hafifuddin Nur, "Pendidikan Indegenous Ala Pesantren untuk Memperkokoh Karakter Generasi Milenial", Edupedia: Jurnal Studi Pendidikan dan Pedagogi Islam, Vol. 5, No. 1, (Juli, 2020), 18.
} 
Situbondo selama kurang lebih satu bulan, pada tanggal 12 Oktober s/d 05 Desember 2015. Kegiatan dan sikap siswa-siswi di SMASa mencerminkan ranah afektif (nilai dan sikap) yang dalam Kurikulum 2013 terkenal dengan istilah kompetensi inti 1 (KI.1) berupa sikap spiritual dan kompetensi inti 2 (KI.2) berupa sikap sosial.

Kegiatan yang dimaksud di atas semisal setiap pagi dimulai jam 06.00 WIB terlaksana rutinitas tadarus oleh siswa di musholla dengan menggunakan speaker sehingga bisa didengar ke seluruh pelosok SMASa. Kegiatan ini dimotori oleh guru PAI sendiri serta merupakan kegiatan ekstrakurikuler RISMA. Guru PAI setengah jam sebelumnya yaitu 05.30 sudah harus berada di musholla untuk memberi teladan kepada anak didiknya. Dilanjutkan dengan kondisi musholla yang selalu penuh dengan siswasiswi untuk melaksanakan salat Dhuba dan berjamaah salat Dzuhur. Kondisi ini mencerminkan akan terealisasinya religiusitas di lingkungan SMAN 1 Situbondo.

Selain itu, di SMAN 1 Situbondo juga dianjurkan untuk melaksanakan 5S; Salam, Senyum, Sapa, Sopan, dan Santun. Semua warga SMASa wajib mendapatkan perlakuan tersebut, siapa pun orangnya, guru, siswa, karyawan, tamu, satpam bahkan kami sebagai peserta PPL. Hal ini menunjukkan betapa di SMASa sangat tinggi menjunjung tinggi nilai kemanusiaan sebagai makhluk sosial. Berangkat dari paparan di atas, maka menjadi sangat menarik untuk mengkaji lebih dalam tentang motivasi siswa dalam meningkatkan sikap spiritual dan sikap sosial serta mengungkap bagaimana upaya guru dalam meningkatkannya.

\section{Perumusan Masalah}

Dari beberapa pemaparan singkat di atas, maka rumusan masalah dalam penelitian ini adalah bagaimana upaya guru PAI meningkatkan sikap spiritual (KI.1) dan sikap sosial (KI.2) siswa?

\section{Tujuan Penelitian}

Mendeskripsikan secara komprehensif tentang upaya guru PAI meningkatkan sikap spiritual (KI.1) dan sikap sosial (KI.2) siswa.

\section{Metode Penelitian}

Penelitian ini menggunakan metode deskriptif yaitu metode penelitian yang berusaha menggambarkan obyek sesuai dengan apa adanya. Objek pada penelitian ini adalah motivasi siswa dalam meningkatkan sikap spiritual dan sikap sosial serta mengungkap bagaimana upaya guru dalam meningkatkannya. Adapun pendekatan penelitian ini adalah pendekatan kualitatif. Untuk memperoleh data penelitian, penulis menggunakan observasi, wawancara, studi dokumentasi. Dalam proses analisis data dengan pendekatan kualitatif terdapat tiga komponen utama yang harus dilaksanakan, yaitu reduksi data, sajian data serta penarikan kesimpulan dan verifikasi.

\section{KERANGKA KONSEPTUAL}

\section{Tinjauan Definitif Motivasi}

Ada ungkapan "motivation is an essential condition of learning". Hasil belajar akan menjadi optimal kalau ada motivasi. Lantas, apa motivasi itu? Dalam Kamus Besar Bahasa Indonesia (KBBI), motivasi adalah dorongan yang timbul pada diri seseorang secara sadar atau tidak sadar untuk melakukan suatu tindakan dengan tujuan tertentu. ${ }^{7}$

Motivasi pada dasarnya adalah kata "motif" yang diartikan sebagai daya upaya yang mendorong seseorang untuk melakukan sesuatu. Dengan kata lain dapat dikatakan sebagai daya penggerak dari dalam dan di dalam subjek untuk melakukan aktivitas-aktivitas tertentu demi mencapai suatu tujuan. Berawal dari kata "motif" itu maka motivasi dapat diartikan sebagai daya penggerak yang telah menjadi aktif. Motif menjadi aktif pada saat-saat tertentu, terutama bila kebutuhan untuk mencapai kebutuhan sangat dirasakan/mendesak. ${ }^{8}$

Menurut Gleitman yang dikutip oleh Mahmud, pengertian dasar motivasi ialah keadaan internal organisme yang mendorongnya untuk berbuat sesuatu. Dalam pengertian ini, motivasi berarti pemasok daya (energizer) untuk bertingkah laku secara terarah. Sedangkan menurut Sumadi

\footnotetext{
7 Moh. Kusnadi, Kamus Lengkeap Bahasa Indonesia, (Surabaya: Cahaya Agency, t.t), 45.

8 Sardiman, Interaksi \& Motivasi Belajar Mengajar, (Jakarta: PT. RajaGrafindo Persada, 2014), 73.
} 
Suryabrata, motif adalah keadaan dalam pribadi seseorang yang mendorong untuk melakukan aktivitas-aktivitas tertentu guna mencapai suatu tujuan. Dalam hal ini motif bukanlah hal yang dapat diamati, melainkan hal yang dapat disimpulkan adanya karena suatu yang dapat disaksikan.?

Motivasi adalah dorongan dasar yang menggerakkan seseorang bertingkah laku. Dorongan ini berada pada diri seseorang yang menggerakkan untuk melakukan sesuatu yang sesuai dengan dorongan dalam dirinya. Oleh karena itu, perbuatan seseorang yang didasarkan atas motivasi tertentu mengandung tema sesuai dengan motivasi yang mendasarinya. ${ }^{10}$

Gray mendefinisikan motivasi sebagai sejumlah proses yang bersifat internal atau eksternal bagi individu yang menyebabkan timbulnya sikap antusiasme dalam hal melaksanakan kegiatan-kegiatan tertentu. ${ }^{11}$

Mc. Donald sebagaimana dikutip oleh Sardiman menjelaskan bahwa, motivasi adalah perubahan energi dalam diri seseorang yang ditandai dengan munculnya feeling dan didahului dengan tanggapan terhadap adanya tujuan. Motivasi akan menyebabkan terjadinya suatu perubahan energi yang ada pada diri manusia, sehingga akan bergayut dengan persoalan gejala kejiwaan, perasaan dan juga emosi, untuk kemudian bertindak atau melakukan sesuatu. $^{12}$

Menurut Usman dikutip oleh Zahroh, motivasi merupakan keinginan yang ada pada diri seorang individu yang mampu merangsang dan mengajaknya untuk melakukan tindakan-tindakan atau sesuatu yang menjadi dasar atau alasan seseorang berperilaku dan berbuat. ${ }^{13}$

Menurut Sardiman, motivasi dapat juga dikatakan serangkaian usaha untuk menyediakan

${ }^{9}$ Kompri, Motivasi Pembelajaran Perspektif Guru dan Siswa, (Bandung: PT. Remaja Rosdakarya, 2015), 2.

${ }^{10}$ Hamzah B. Uno, Teori Motivasi dan Pengukurannya, (Jakarta: Bumi Aksara, 2011), 1.

${ }^{11}$ Abdul Majid, Strategi Pembelajaran, (Bandung: PT. Remaja Rosdakarya, 2014), 307.

${ }^{12}$ Sardiman, Interaksi \& Motivasi Belajar Mengajar, (Jakarta: PT. RajaGrafindo Persada, 2014), 73.

${ }^{13}$ Aminatul Zahroh, Membangun Kualitas Pembelajaran Melalui Dimensi Profesionalisme Guru, (Bandung: CV. Yrama Widya), 239. kondisi-kondisi tertentu sehingga seseorang mau dan ingin melakukan sesuatu, dan bila ia tidak suka maka akan berusaha untuk meniadakan atau mengelakkan perasaan tidak suka itu. Jadi, motivasi itu dapat dirangsang oleh faktor dari luar tetapi motivasi itu tumbuh di dalam diri seseorang. ${ }^{14}$

Menurut Kompri, motivasi dapat diartikan sebagai kekuatan atau energi seseorang yang dapat menimbulkan tingkat persistensi dan antusiasmenya dalam melaksanakan suatu kegiatan, baik yang bersumber dari dalam diri individu itu sendiri maupun dari luar individu. ${ }^{15}$

Jadi, motivasi merupakan jantungnya proses pembelajaran dan elemen penting dalam dunia pendidikan. Oleh karenanya, tugas guru yang pertama adalah membangkitkan atau membangun motivasi siswa, sehingga siswa giat dan senang untuk belajar dan akhirnya dengan mudah menyerap ilmu dan pengetahuan dalam proses pembelajaran.

\section{Tinjauan Tentang Upaya Guru}

Dalam kegiatan belajar mengajar, guru merupakan salah satu komponen penting dan mempunyai peran yang sangat besar. Salah satu peran guru yang sangat penting adalah meningkatkan keinginan atau motivasi siswa untuk belajar. Dalam hal ini, guru harus mempunyai upaya yang efektif dalam melakukan tugas tersebut. Upaya yang dimaksud bisa berupa penggunaan strategi, metode, atau teknikteknik yang baik.

Dalam melakukan tugas tersebut, guru perlu memahami siswa dengan baik agar nantinya guru mampu menyediakan pengalaman-pengalaman pembelajaran sehingga siswa bisa menemukan sesuatu yang menarik, bernilai, terdorong secara intrinsik, dan berguna bagi mereka. ${ }^{16}$ Mc Carty dan Siccone dalam Sumarno menjelaskan bahwa, semakin baik guru memahami minat-minat siswa dan menilai tingkat keterampilan siswa, maka semakin efektif dan menjangkau mengajari mereka. ${ }^{17}$

\footnotetext{
${ }^{14}$ Sardiman, Interaksi \& Motivasi Belajar Mengajar, (Jakarta: PT. RajaGrafindo Persada, 2014), 75.

${ }^{15}$ Kompri, Motivasi Pembelajaran Perspektif Guru dan Siswa, (Bandung: PT. Remaja Rosdakarya, 2015), 3.

${ }^{16}$ Kompri, Motivasi Pembelajaran Perspektif Guru dan Siswa, (Bandung: PT. Remaja Rosdakarya, 2015), 242.

17 Kompri, Motivasi Pembelajaran Perspektif Guru dan Siswa, (Bandung: PT. Remaja Rosdakarya, 2015), 243.
} 
Menurut Kamus Besar Bahasa Indonesia, upaya adalah usaha. ${ }^{18}$ Sedangkan guru dapat diartikan juga sebagai orang yang tugasnya terkait dengan upaya mencerdaskan kehidupan bangsa dalam semua aspeknya, baik spiritual, intelektual, emosional, fisik, maupun aspek lainnya, juga sebagai fasilitator agar siswa dapat belajar dan mengembangkan potensi dan kemampuan secara optimal melalui pendidikan sekolah, baik yang didirikan oleh pemerintah maupun oleh masyarakat atau swasta. ${ }^{19}$

Dengan demikian, dalam pandangan umum guru tidak hanya dikenal secara formal sebagai pendidik, pengajar, pelatih dan pembimbing, tetapi juga sebagai "sosial agent hired by society to help facilitate members of society who attend schools" atau agen sosial yang diminta oleh masyarakat untuk memberikan bantuan kepada warga masyarakat yang akan dan sedang berada di bangku sekolah. ${ }^{20}$

Menurut Ahmad Tafsir yang dikutip Heri Gunawan, Pendidikan Agama Islam adalah bimbingan yang diberikan seseorang kepada seseorang agar ia berkembang secara maksimal sesuai dengan ajaran Islam. ${ }^{21}$ Azizy dalam buku Abdul Majid mengemukakan bahwa esensi pendidikan yaitu adanya proses transfer nilai, pengetahuan, dan keterampilan dari generasi tua kepada generasi muda agar generasi muda mampu hidup. Oleh karena itu, ketika kita menyebut pendidikan Islam maka akan mencakup dua hal yakni mendidik siswa untuk berperilaku sesuai dengan nilai-nilai atau akhlak Islam dan mendidik siswa-siswi untuk mempelajari materi agama Islam, subjek berupa pengetahuan tentang ajaran Islam. ${ }^{22}$

Pendidikan Agama Islam adalah upaya sadar dan terencana dalam menyiapkan peserta didik untuk mengenal, memahami, menghayati hingga mengimani, bertakwa dan berakhlak mulia dalam mengamalkan ajaran agama Islam dari sumber utamanya yakni kitab suci Alquran dan Hadits

\footnotetext{
${ }^{18}$ Moh. Kusnadi, Kamus Lengkap Bahasa Indonesia, (Surabaya: Cahaya Agency, t.t), 86.

${ }^{19}$ Suparlan, Guru sebagai Profesi, (Yogyakarta: Hikayat Publishing, 2006), 10.

${ }^{20}$ Suparlan, Guru sebagai Profesi, (Yogyakarta: Hikayat Publishing, 2006), 10.

${ }^{21}$ Heri Gunawan, Pendidikan Karakter: Konsep dan Implementasi, (Bandung: CV. Alfabeta, 2014), 96.

${ }^{22}$ Abdul Majid, Belajar dan Pembelajaran Agama Islam, (Bandung: PT. Remaja Rosda Karya, 2012), 12.
}

melalui kegiatan bimbingan, pengajaran, latihan, serta penggunaan pengalaman. Disertai juga dengan tuntunan untuk menghormati penganut agama lain dalam hubungannya dengan kerukunan antar umat beragama dalam masyarakat hingga terwujud kesatuan dan persatuan bangsa.

Jadi, upaya guru pendidikan agama Islam (PAI) merupakan usaha sadar yang dilakukan pendidik dalam mempersiapkan peserta didik untuk meyakini, memahami, dan mengamalkan ajaran Islam melalui kegiatan bimbingan, pengajaran, atau pelatihan yang telah direncanakan atau diprogramkan untuk mencapai tujuan yang telah ditetapkan, yakni menjadikan peserta didik khoiru al-ummah.

Menurut Kompri, ada 5 upaya yang dapat dilakukan guru untuk membangkitkan motivasi siswa. Pertama, membuat persiapan untuk menggunakan cara atau metode dan media mengajar yang bervariasi, sehingga kebosanan siswa dapat dikurangi atau dihilangkan. Kedua, merencanakan dan memilih bahan yang menarik minat dan dibutuhkan oleh siswa. Ketiga, menciptakan belajar yang menyenangkan, jauh dari intimidasi dan penyiksaan. Keempat, menganjurkan untuk membaca buku penunjang atau melihat video yang memuat kisah-kisah orang sukses. Kelima, guru harus banyak memberi contoh langsung melalui perbuatan, bukan hanya sekadar kata-kata dan teori.

\section{PEMBAHASAN}

\section{Motivasi Siswa dalam Meningkatkan Sikap Spiritual dan Sikap Sosial}

\section{Motivasi Intrinsik}

Kesadaran akan dirinya bahwa mereka adalah manusia beragama dan harus menaati norma-norma agama yang berlaku serta kesadaran sebagai makhluk sosial menjadikan siswa-siswi SMAN 1 Situbondo aktif selalu sebagai pelaku dan penggerak bagi yang lain untuk melaksanakan sikap spiritual dan sosial. Sedini mereka sudah dibiasakan untuk selalu taat akan aturan serta ramah dan baik dalam menjalin hubungan.

Kebiasan yang dimaksud adalah sejak dini mereka sudah dilatih untuk selalu taat akan aturan, sehingga ketika dewasa mereka tidak lagi membutuhkan rangsangan dan tidak perlu disuruh 
untuk melakukan pekerjaan yang sudah terbiasa dilakukan semasa kecilnya. Kalau pun ada rangsangan mungkin hanya sekilas dan sedikit saja, sebagaimana pengakuan Bapak Masduki, M.Pd.I selaku guru PAI kelas XI.

Adapun fakta bahwa siswa melakukan hal-hal yang masuk kategori afektif (nilai dan sikap) tersebut dikarenakan kesadaran diri mereka sendiri sehingga tidak memerlukan dorongan dari luar dirinya. Hal ini menurut Sardiman disebut motivasi intrinsik Disebutkan bahwa yang dimaksud motivasi intrinsik adalah motif-motif yang menjadi aktif atau berfungsinya tidak perlu dirangsang dari luar, karena dalam diri setiap individu sudah ada dorongan untuk melakukan sesuatu. ${ }^{23}$

Indikator dari motivasi intrinsik itu sendiri yaitu adanya hasrat dan keinginan berhasil, adanya dorongan dan kebutuhan dalam belajar, dan adanya harapan dan cita-cita masa depan. Haziq Jauhary mengatakan bahwa, "Motivasi yang muncul dari dalam, misalnya minat atau keingintahuan, sehingga anda tidak lagi termotivasi oleh bentuk-bentuk intensif atau hukuman, lebih merupakan motivasi instrinsik." ${ }^{24}$

Maka fakta siswa-siswi melakukan kegiatankegiatan yang masuk dalam ranah afektif (nilai dan sikap), semisal istikamah salat Dhuha dan jamaah salat Drubur, serta saling tegur sapa dan bersalaman kepada guru dan sesama teman, karena berangkat dari kesadaran diri mereka untuk menjadi pribadi yang baik, ini sejalan dengan salah satu indikator motivasi intrinsik menurut Hamzah B. Uno. Indikator yang dimaksud adalah adanya dorongan diri sendiri, memiliki harapan serta dan cita-cita masa depan.

Dari paparan di atas, dapat dilihat bahwa sikap siswa-siswi di SMAN 1 Situbondo sudah melaksanakan persyaratan salah satu kompetensi dalam Kurikulum 2013, yaitu sikap spiritual (KI-1) dan sikap sosial (KI-2). Mereka melaksanakan kegiatan-kegiatan yang masuk dalam kedua kompetensi tersebut tanpa paksaan dari pihak luar, dalam arti berangkat dari kesadaran bahwa mereka

\footnotetext{
${ }^{23}$ Sardiman, A.M, Interaksi \& Motivasi Belajar Mengajar, (Jakarta: PT. RajaGrafindo Persada, 2014), 90.

${ }^{24}$ Haziq Jauhary, Membangun Motivasi, (Semarang: CV. Ghiyas Putra, 2008), 7.
}

harus menaati aturan, memperbaiki diri, sopan santun, saling berkomunikasi dalam hal kebaikan agar bisa menjadi pribadi yang diharapkan, baik dari sisi religiusitas ataupun sosialnya.

Selain itu, faktor kebiasaan menjadi hal yang penting dalam motivasi siswa untuk mengaplikasikan ranah afektifnya. Pernyataan Bapak Masduki dalam wawancara memberitahukan bahwa anak didik itu supaya diajari dan diikutsertakan melakukan hal-hal yang baik dimulai sejak dini, sehingga ketika sudah dewasa terbiasa melakukan kebaikan-kebaikan yang biasa dilakukan sejak kecil, sebagaimana ungkapan "Untuk bisa, maka harus terbiasa".

\section{Motivasi Ekstrinsik}

Tidak semua peserta didik di SMAN 1 Situbondo memiliki motivasi yang berasal dari dalam dirinya dalam hal melaksanakan kegiatan yang ada kaitannya dengan aspek sikap, baik sikap spiritual atau sosial. Dari beberapa hasil wawancara bersama informan disebutkan bahwa selain faktor internal, siswa juga membutuhkan rangsangan dari luar dirinya.

Guru, teman, dan lingkungan sekolah juga bisa mempengaruhi semangat dan motivasi siswa dalam kegiatan belajarnya. Sebagaimana yang dinyatakan oleh saudara Ahmadi Anwarul Fahmi yang merupakan siswa kelas XI IPA-1 bahwa siswa terdorong untuk melaksanakan kegiatan religius dan sosial tidak terlepas dari keaktifan guru dalam membina dan membimbing anak didiknya.

Menurut Bapak Masduki, sebagai informan perwakilan dari kalangan guru di SMASa bahwa guru juga ikut berperan dalam menyukseskan kepribadian anak menjadi siswa yang taat beragama, taat aturan sekolah serta berinteraksi dengan baik kepada semua warga SMASa. Usaha guru yang dimaksud di atas berupa mengkondisikan suasana lingkungan yang kondusif serta menyediakan sarana yang memadai untuk terlaksananya kegiatan yang dimaksud dalam penelitian ini, sebagaimana hasil observasi selama sebulan di sekolah tersebut.

Berdasarkan paparan hasil penelitian di atas, jika dihubungkan dengan teori motivasi tentang macam atau jenis motivasi, maka hal tersebut masuk dalam kategori motivasi ekstrinsik. Sebagaimana Sardiman menyebutkan bahwa, motivasi ekstrinsik 
adalah motivasi yang aktif dan berfungsi karena adanya pengaruh atau rangsangan dari luar..$^{25}$

Fakta bahwa kepala sekolah, guru serta karyawan di SMAN 1 Situbondo selalu continue dalam membimbing dan membina anak-anak didiknya merupakan salah satu faktor eksternal dalam teori motivasi. Faktor eksternal yang dimaksud adalah faktor sekolah, meliputi metode mengajar, kurikulum, relasi antara guru dan siswa, relasi siswa dengan siswa, standar sekolah, suasana dan kondisi tempat belajar. ${ }^{26}$

Indikator motivasi ekstrinsik juga terdapat dalam deskripsi hasil penelitian di atas, yaitu lingkungan yang kondusif. Hamzah B. Uno mengklasifikasi indikator motivasi menjadi enam, tiga di antaranya termasuk indikator motivasi ekstrinsik, salah satunya adalah adanya lingkungan belajar yang kondusif, baik di dalam atau di luar kelas. ${ }^{27}$

Melihat paparan di atas, semua siswa di SMAN 1 Situbondo melaksanakan kegiatan belajar karena kesadaran dirinya agar menjadi siswa yang terpelajar dan terdidik. Sebagian dari mereka butuh dorongan dan rangsangan dari luar untuk belajar. Rangsangan luar yang dimaksud adalah baik dari guru, sesama teman, lingkungan serta keluarga di rumah.

Dorongan dari dalam (intrinsik) bisa terwujud jika diawali dari rangsangan luar (ekstrinsik). Bapak Syamsul Ma'arif selaku kepala sekolah di SMAN 1 Situbondo mengatakan bahwa, “... salah satu usaha saya dan para guru di sini yang sudah terealisasi adalah menganjurkan siswi berkerudung dan memakai rok panjang. Alhamdulillah, sekarang bisa anda lihat sendiri. Ini juga merupakan salah satu untuk menyukseskan aspek afektif dalam K-13". Hal tersebut juga diperkuat dengan hasil wawancara bersama Bapak Sanusi, yang notabene siswa baru butuh arahan dan bimbingan agar bisa menyesuaikan dengan kondisi lingkungan dan aturan di SMAN 1 Situbondo. ${ }^{28}$

\footnotetext{
${ }^{25}$ Sardiman, A.M, Interaksi \& Motivasi Belajar Mengajar, (Jakarta: PT. RajaGrafindo Persada, 2014), 91.

${ }^{26}$ Sofan Amri, Pengembangan dan Model Pembelajaran dalam Kurikulum 2013, (Jakarta: PT. Pustaka Prestasi, 2013), 26.

${ }^{27}$ Hamzah B. Uno, Teori Motivasi dan Pengukurannya, (Jakarta: Bumi Aksara, 2011), 7.

${ }^{28}$ Bapak Sanusi, M.Pd.I, Guru PAI kelas X di SMAN 1 Situbondo, Wawancara, 02 Mei 2016.
}

Dari sini dapat dilihat bahwa bagaimana pun motivasi intrinsik ada dalam diri siswa pastilah terbentuknya berawal dari motivasi ekstrinsik. Dicontohkan, bahwa salah satu siswa sangat rajin berjamaah Dzuhur di mushalla. Rajinnya siswa tersebut ada kemungkinan karena di rumahnya selalu diajak berjamaah oleh orang tuanya, atau ia mendengarkan penjelasan guru saat di kelas yang menerangkan bahwa salat berjamaah pahalanya 27 kali lipat daripada salat sendirian. Hal ini sebagaimana diungkapkan oleh Sardiman bahwa motivasi itu dapat dirangsang oleh faktor dari luar tetapi motivasi itu tumbuh di dalam diri seseorang. ${ }^{29}$

Jika dikaitkan dengan teori Hierarki Kebutuhan menurut Abraham Maslow, fakta penelitian di atas memang motivasi siswa bermula dari kebutuhan dari luar yang sudah terpenuhi, sehingga ada tuntutan untuk memenuhi kebutuhan dalam diri siswa. Artinya, secara hierarki kebutuhan terendah dari siswa SMAN 1 Situbondo, yakni kebutuhan rasa aman dan stabilitas, kebutuhan akan kasih sayang guru dan sesama teman SMASa, dan kebutuhan berprestasi sudah terpenuhi, sehingga tersisa kebutuhan tertinggi, yaitu kebutuhan mengaktualisasikan diri (intrinsik).

Terlepas dari mana yang terlebih dahulu membentuk motivasi pada seseorang, berdasar sudut pandang subjektif tetaplah motivasi intrinsik yang baik dan terbaik. Pertama, karena kita dianjurkan untuk selalu ikhlas dalam melakukan setiap pekerjaan bukan karena alasan yang lain. Imam Ahmad ibn Ruslan menyebutkan dalam syairnya, ${ }^{30}$

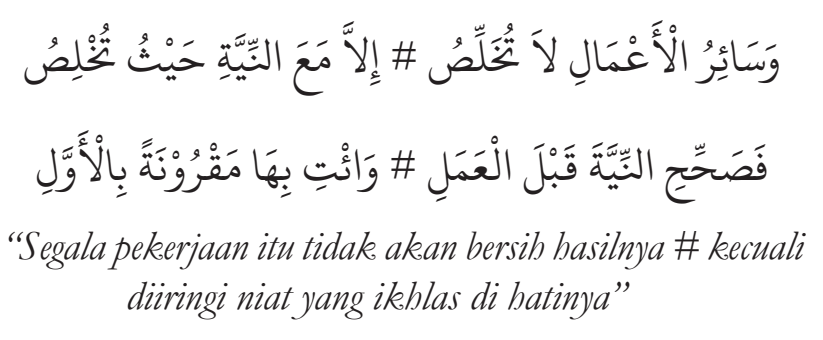

"Oleh karenanya, perbaiki niatmu sebelum bekerja \# lakukan niat itu sejak semula"

\footnotetext{
${ }^{29}$ Sardiman, A.M, Interaksi \& Motivasi Belajar Mengajar, (Jakarta: PT. RajaGrafindo Persada, 2014), 75.

${ }^{30}$ Ahmad Ibn Ruslan, Matnu al-Zubad, (Surabaya: al-Hidayah, t.th.), 4 .
} 
Kedua, karena motivasi yang bersumber dari dalam itu tidak akan mudah goyah dan tetap berpegang teguh pada pendiriannya. Jika kita bergantung pada hal di luar diri kita, maka saat sesuatu yang menjadi tempat bergantung itu tiada, akan jatuh terpuruk dan kembali ke kondisi sebelum kita bergantung padanya. Sebagaimana yang diungkapkan oleh Nashar bahwa motivasi yang lebih baik adalah motivasi yang timbul dari dalam diri manusia dibandingkan dengan motivasi yang datang dari luar diri manusia". ${ }^{31}$

\section{Upaya Guru PAI Meningkatkan Motivasi Siswa dalam Sikap Spiritual dan Sikap Sosial}

1. Menciptakan Suasana lingkungan yang Kondusif

Berdasarkan hasil observasi, terlihat sekali keadaan sekolah yang sangat mendukung untuk terealisasinya aspek afektif,. Hal ini bisa dibuktikan dengan kondisi tempat ibadah (mushalla) yang sejuk dan asri disertai perlengkapan yang lengkap, semisal tempat wudlu, mukena serta Alquran. ${ }^{32}$

Dari sisi sosialnya, siswa SMASa terkenal sangat ramah dan mudah akrab. Adapun hal yang menakjubkan ialah ketika melihat kebiasaan mereka saling tegur sapa dengan sesama siswa, juga kebiasaan bersalaman kepada guru dan staf sekolah ketika mereka bertemu. ${ }^{33}$

Semua hasil observasi tersebut di atas, diperkuat dengan pernyataan Bapak Masduki tentang keaktifan ekstra RISMA dalam menghidupkan suasana belajar di sekolah melalui kegiatan pengajian dan kajian seputar keagamaan dan diskusi. Berikut pernyataannya,

"Lah, kalau persoalan itu pihak sekolah punya langkah, yaitu melalui pembinaan ekstra RISMA. Jadi mereka mengadakan pengajian dan kajian khusus tentang keagamaan, syariah, akidah, akhlak, dsb. Ada semacam sharing ide, diskusi bersama. Juga dari sisi sosial, RISMA bekerja sama dengan OSIS mengadakan santunan ke salah satu panti asuhan, juga ke anak yatim." ${ }^{34}$

\footnotetext{
${ }^{31}$ Nashar, Peranan Motivasi dan Kemampuan Awal dalam Kegiatan Pembelajaran, (Jakarta: Delia Press, 2004), 57.

${ }^{32}$ Observasi di SMAN 1 Situbondo, 17 April - 17 Mei 2016.

${ }^{33}$ Observasi di SMAN 1 Situbondo, 17 April - 17 Mei 2016.

${ }^{34}$ Bapak Ahmad Masduki, M.Pd.I, Guru PAI kelas XI di SMAN 1 Situbondo, Wawancara, 02 Mei 2016.
}

Fakta tersebut di atas, jika direlasikan dengan teori-teori tentang bentuk upaya guru PAI maka jelas bahwa mengkondusifkan suasana dan iklim lingkungan sehingga terasa nyaman dan aman bagi siswa merupakan salah satu indikator penting dalam efektifitas dan keberhasilan proses pendidikan dan pembelajaran. Hal ini tidak hanya satu pakar yang menyebutkan, melainkan semua pakar pendidikan yang menawarkan upaya apa yang seharusnya dilakukan oleh guru dalam membangun rangsangan siswa untuk belajar.

Dengan demikian, usaha guru PAI di SMAN 1 Situbondo sudah berjalan dengan baik serta terbukti hasilnya. Semboyan 5S yang ada di SMAN 1 Situbondo menjadi salah satu bukti upaya pihak sekolah agar tercipta iklim sosial yang tinggi dan religiusitas yang sempurna. Sebagaimana perkataan saudari Ulussinniyyah Fauziyah dalam wawancaranya,

"Iya, hal ini dibuktikan dengan adanya salah satu misi di sekolah ini adalah melaksanakan 5S; senyum, salam, sapa, sopan, dan santun. Oleh karena itu saya rasa misi tersebut sudah mewakili apa yang dilakukan warga SMASa, khususnya siswanya." ${ }^{35}$

2. Membangkitkan Hasrat dan Minat Menjadi Lebih Baik

Siswa akan terdorong untuk belajar dan mudah untuk menyerap pelajaran manakala mereka memiliki kemauan serta minat yang tinggi. Melalui pembinaan dan pembiasaan dari guru terhadap siswanya sehingga tercipta dalam diri siswa sebuah hasrat dan minat untuk menjadi pribadi yang baik, seperti yang telah diungkapkan oleh guru PAI di SMAN 1 Situbondo

Hal tersebut bisa tercapai jika seorang guru bisa memahami karakter dan kemauan peserta didik. Pemahaman terhadap peserta didik sangat membantu guru dalam membangun sikap spritiual dan sosial dengan mengembangkan pembelajaran yang efektif dan kreatif, sebagaimana yang telah disebutkan Mulyasa. ${ }^{36}$

\footnotetext{
${ }^{35}$ Ulusinniyyah Fauziyah, Siswi kelas XI IPS-1 di SMAN 1 Situbondo, Wawancara, 26 April 2016.

${ }^{36}$ E. Mulyasa, Guru dalam Implementasi Kurikulum 2013, (Bandung: PT. Remaja Rosdakarya, 2015), 106.
} 
Banyak cara yang bisa dilakukan oleh guru untuk menumbuhkan minat dan hasrat belajar siswa, khususnya terkait dalam peningkatan sikap spiritual dan sikap sosial. Yaitu dengan melibatkan seluruh siswa tanpa membeda-bedakan, untuk aktif dalam kegiatan yang berorientasi religious serta ada kaitannya dengan sikap spiritual dan sosial.

Jadi, guru tidak hanya monoton pada satu kelompok siswa saja, seperti ekstra RISMA sebagaimana dalam konteks penelitian ini. Akhmad Sudrajat mengatakan, “...jangan jadikan siswa peserta didik yang pasif karena dapat menurunkan minat dan motivasi siswa."

\section{Menggunakan Metode yang Beragam}

Sebagaimana pengakuan Bapak Sanusi, bahwa banyak cara yang dilakukan oleh guru agar siswa bisa memenuhi Standar Kompetensi Lulusan (SKL) khususnya pada ranah afektif (sikap dan nilai). Pengakuan tersebut dibenarkan oleh Bapak Masduki selaku guru PAI kelas XI.

Salah satu cara yang bisa disimpulkan dari hasil wawancara dan observasi ialah guru PAI telah menggunakan metode uswah (keteladanan), metode mav'idah, dan metode pembiasaan.

Metode uswah dan mau'idah yang dimaksud adalah sebagaimana pernyataan Bapak Masduki ketika diwawancarai,

"Jadi, yang terpenting itu guru harus memberi contoh. Gak bisa guru itu hanya menyuruh saja, anak-anak akan membantah nanti. Bapak hanya bisa nyuruh tapi bapak sendiri gak pernah salat duha, gak ngaji, begitu pas kata anak-anak. Makanya, saya itu harus mavidzatun hasanah, tidak hanya mengajarkan materi tapi juga dengan pendekatan persuasif." ${ }^{37}$

Hal ini sesuai dengan apa yang disebutkan Kompri bahwa, “...guru itu harus banyak memberi contoh langsung melalui perbuatan, bukan hanya sekadar kata-kata dan teori." ${ }^{38}$ Salah satu yang termasuk metode pembiasaan adalah yang telah

\footnotetext{
${ }^{37}$ Bapak Ahmad Masduki, M.Pd.I, Guru PAI kelas XI di SMAN 1 Situbondo, Wawancara, 02 Mei 2016.

${ }^{38}$ Kompri, Motivasi Pembelajaran Perspektif Guru dan Siswa, (Bandung: PT. Remaja Rosdakarya, 2015), 249.
}

dilakukan oleh Bapak Sanusi, yakni membiasakan siswa kelas $\mathrm{X}$ dengan hafalan juz 'Amma dengan tujuan untuk melatih siswa senang terhadap pedoman utama umat Islam; Alquran.

Terdapat banyak cara untuk terciptanya pembelajaran yang baik dan efektif. Cara yang dimaksud bisa berupa strategi, teknik atau metode. Untuk SMAN 1 Situbondo sendiri, guru mata pelajaran PAI sudah berusaha semaksimal mungkin dengan penggunaan beberapa metode yang telah disebut di atas. Dan itu semua sesuai dengan teori para pakar pendidikan tentang upaya guru dalam membantu siswa mencapai SKL yang telah ditetapkan.

Adapun metode yang tepat merupakan salah satu kunci guru untuk menyukseskan kegiatan belajar mengajarnya. Namun, jika guru hanya menggunakan satu metode saja maka akan membuat siswa merasa jenuh, bosan, dan tidak tertarik sehingga apa yang disampaikan dan yang dipraktikkan oleh guru menjadi sia-sia karena siswa akan mengabaikannya.

4. Menghindari Ancaman, Sanksi, dan Komentar Buruk

Menjadi suatu prinsip tersendiri bagi warga, khususnya guru dan karyawan di SMAN 1 Situbondo bahwa mereka tidak boleh serta merta tanpa alasan yang mendesak berbuat kekerasan serta berucap kata-kata yang sekiranya membuat siswa sakit hati dan akhirnya mereka mengabaikan titah dari para guru. Hal ini disampaikan dengan tegas dan jelas oleh Bapak Masduki.

Jika fakta tersebut dikaitkan dengan teori yang telah dipaparkan di atas, maka para pakar pendidikan berbeda pendapat. Perbedaan pendapat yang dimaksud adalah pendidik harus menghindari semua jenis hukuman dan ancaman kepada peserta didiknya, karena lebih banyak sisi negatif yang diperoleh ketimbang sisi positifnya. Hal ini diwakili oleh Akhmad Sudrajat. Sementara menurut Wina Sanjaya dan Mulyasa, guru boleh-boleh saja memberi hukuman kepada siswa karena hal itu bisa membuat jera.

Adapun perbedaan pendapat di atas sebenarnya memiliki muara yang sama. Artinya bahwa hukuman dan yang semacamnya bisa dilakukan tapi harus sewajar dan sekadarnya saja, tidak boleh 
melampaui batas dan keluar dari sisi kemanusiaan dan predikat guru sebagai pengayom. Karena, jika siswa yang nakal dibiarkan dan tidak ada tindakan maka ia akan semakin menjadi nakal dan menganggap bahwa perbuatan nakal itu hal yang diperbolehkan.

Demikian juga, jika penindakan guru keterlaluan maka bukan malah sembuh, bahkan ia akan memberontak dan merugikan siswa. Mengutip perkataan Wina Sanjaya bahwa, "Menyadarkan siswa dengan cara mengancam dan memberi hukuman lebih banyak ruginya. Jika masih bisa dengan cara yang positif, sebaiknya hindari cara yang negatif." ${ }^{39}$

\section{Memberikan Penilaian}

Berdasarkan hasil wawancara dengan Bapak Sanusi, bahwa salah satu program yang telah dibuat oleh guru-guru di sana adalah memberikan penilaian pribadi terhadap siswa-siswinya, yang kemudian hal itu digunakan untuk evaluasi bersama. Dalam Kurikulum 2013 memang ada tiga komponen kompetensi yang harus dipenuhi oleh siswa, yaitu aspek sikap, kognitif, dan psikomotorik. ${ }^{40}$ Sehingga guru mempunyai tugas tambahan selain memberi penilaian aspek kognitif dan psikomotorik, juga harus menilai aspek sikap keseharian siswa dan spiritualnya.

Menurut Wina Sanjaya, banyak siswa yang belajar karena ingin memperoleh nilai yang bagus. Bagi sebagian siswa nilai bisa menjadi motivasi yang kuat untuk belajar. Oleh karenanya, hal ini dimasukkan dalam salah satu upaya yang bisa dilakukan oleh guru untuk memotivasi dan meningkatkan sikap spiritual dan sosial siswa.

Dalam hal ini, tentu sangatlah tepat dengan upaya guru SMAN 1 Situbondo yang diperkuat oleh Wina Sanjaya. Selain juga karena dalam K-13, penilaian memang suatu kewajiban guru dalam melihat SKL (Standar Kompetensi Lulusan) siswa, apakah sudah memenuhi standar atau belum. Penilaian ini dilakukan setiap hari oleh guru dalam proses pembelajaran, sehingga tidak melulu melihat aspek kognitif semata, tapi juga attitude dan value harus diperhatikan.

\footnotetext{
${ }^{39}$ Wina Sanjaya, Pembelajaran dalam Implementasi Kurikulum Berbasis Kompetensi (KBK), Jakarta: Kencana Prenada Media Group, 2011), 255.

${ }^{40}$ E. Mulyasa, Pengembangan dan Implementasi Kurikulum 2013, (Bandung: PT. Remaja Rosdakarya, 2014), 66.
}

6. Membangun Sikap Spiritual dan Sosial dengan Kecerdasan Emosional

Usaha demi usaha selalu dilakukan oleh guru di SMAN 1 Situbondo agar anak didiknya menjadi pribadi yang diharapkan. Melalui kegiatan ektrakurikuler RISMA, guru memfasilitasi siswa-siswi untuk bisa beraksi dan bereaksi mengasah kemampuan mereka, khususnya terkait ranah afektifnya; spiritual dan sosialnya. Demikian penegasan Bapak Masduki dalam jawaban wawancaranya.

Upaya guru PAI di SMASa tersebut sebagai sebuah pengejawantahan dari teori bahwa emosi yang cerdas dapat memasuki perasaan dan pikiran orang lain, juga mampu membuat situasi dan kondisi menjadi lebih berenergi positif. Sehingga perlu reorientasi terhadap paradigma keberhasilan yang hanya menekankan aspek kognitif dan keterampilan teknis ke arah pengembangan nonkognitif, interaksi sosial, rasa bertanggung jawab, dan aspek emotional. ${ }^{41}$

Membangun sikap spiritual dan sosial memang seharusnya dimulai dari jiwa itu sendiri. Karena sikap spiritual dan sosial merupakan pekerjaan hati, sehingga hati dan jiwalah yang seharusnya di-manage terlebih dahulu. Sehingga pada akhirnya tercipta pribadi siswa yang memiliki ESQ (Emotional Spiritual Quotient) tinggi. Ketika siswa telah memiliki ESQ yang memadai maka akan mudah bagi guru untuk menanamkan nilai-nilai agama dan menyadarkannya sebagai makhluk sosial.

7. Terus Mengawasi Siswa dan Melakukan Perbaikan Berkesinambungan

Selalu mengawasi, membina, dan mengingatkan para anak didiknya merupakan ke sekian upaya guru PAI di SMAN 1 Situbondo. Demikian hasil observasi yang telah dilakukan di sana, yakni tidak ada percakapan guru dengan siswa kecuali pasti diselingi dengan wejangan dan peringatan agar selalu menjadi siswa yang baik, secara lahir maupun batinnya. Dalam hal ini Bapak Sanusi berkata,

"Ya, yang namanya kendala pasti ada. Jadi, bagaimana kita guru harus berusaha membina serta memperbaikinya. Keragaman siswa dalam satu kelas misalnya, kita harus laten, terus-menerus dan continue dalam

\footnotetext{
${ }^{41}$ Mulyasa, E. Mulyasa, Guru dalam Implementasi Kurikulum 2013, (Bandung: P'T. Remaja Rosdakarya, 2015), 127.
} 
membina, insya-Allab mereka akan berubah dan terbiasa. Dan Alhamdulillah, hingga semester genap ini perubahan sangat terasa dan signifikan." ${ }^{42}$

Menurut Mulyasa, sekolah beserta komponenkomponennya harus melakukan perbaikan secara terus menerus dan berkesinambungan terkait kegiatan-kegiatan yang telah dijalankan oleh siswa. Guru sebagai salah satu komponen pendidikan tidak boleh putus asa ketika anak didiknya selalu gagal dalam pembelajaran dan mendapatkan hasil yang kurang maksimal.

Segala hal yang telah diupayakan guru PAI di SMASa dengan melakukan perbaikan berkesinambungan adalah merupakan usaha yang sesuai dengan tuntunan pendidikan Islam. Kontinyuitas merupakan kunci keberhasilan seseorang. continue dan konsisten merupakan indikasi bahwa orang tersebut memiliki jiwa semangat yang tinggi dan cita-cita yang mulia. Mungkin continue dalam melakukan perbaikan merupakan manifestasi ungkapan dari, "Hari ini harus lebih baik dari kemarin, dan hari esok harus lebih baik dari hari ini." Itulah slogan yang harus dipegang teguh oleh guru dan siswa.

\section{SIMPULAN}

Penelitian ini menghasilkan beberapa temuan tentang upaya guru PAI meningkatkan motivasi siswa dalam sikap spiritual dan sikap sosial, di antaranya adalah terus mengawasi siswa dan melakukan perbaikan berkesinambungan, membangun sikap spiritual dan sosial dengan kecerdasan emosional, memberikan penilaian. Selain itu juga menghindari ancaman, sanksi, dan komentar buruk. Menggunakan metode yang beragam, membangkitkan hasrat dan minat menjadi lebih baik, menciptakan suasana lingkungan yang kondusif.

\footnotetext{
${ }^{42}$ Bapak Sanusi, M.Pd.I, Guru PAI kelas X di SMAN 1 Situbondo, Wawancara, 02 Mei 2016.
}

\section{DAFTAR RUJUKAN}

Abdullah, Abdurrahman Saleh. Teori-teori Pendidikan Berdasarkan al-Qur'an, (Jakarta: PT. Rineka Cipta, 2007.

Alma, Buchari, Dkk. Guru Profesional. Bandung: Alfabeta, 2014.

Amri, Sofan. Pengembangan dan Model Pembelajaran dalam Kurikulum 2013. Jakarta: PT. Pustaka Prestasi, 2013.

Fauzi, Imron. Manajemen Pendidikan ala Rasulullah. Jogjakarta: Ar-Ruzz Media, 2012.

Gunawan, Heri. Pendidikan Karakter: Konsep dan Implementasi. Bandung: CV. Alfabeta, 2014.

Jauhary, Haziq Membangun Motivasi. Semarang: CV. Ghiyas Putra, 2008.

Kompri. Motivasi Pembelajaran Perspektif Guru dan Siswa. Bandung: PT. Remaja Rosdakarya, 2015.

Kusnadi, Moh. Kamus Lengkap Bahasa Indonesia. Surabaya: Cahaya Agency, t.th.

Majid, Abdul. Belajar dan Pembelajaran Agama Islam. Bandung: PT. Remaja Rosda Karya, 2012.

Majid, Abdul. Strategi Pembelajaran. Bandung: PT. Remaja Rosdakarya, 2014.

Moh. Nawafil dan Hafifuddin Nur, "Pendidikan Indegenous Ala Pesantren untuk Memperkokoh Karakter Generasi Milenial", Edupedia: Jurnal Studi Pendidikan dan Pedagogi Islam, Vol. 5, No. 1, (Juli, 2020).

Mulyasa, E. Guru dalam Implementasi Kurikulum 2013. Bandung: PT. Remaja Rosdakarya, 2015.

Mulyasa, E. Pengembangan dan Implementasi Kurikulum 2013. Bandung: PT Remaja Rosdakarya, 2014.

Nashar. Peranan Motivasi dan Kemampuan Awal dalam Kegiatan Pembelajaran. Jakarta: Delia Press, 2004

Ruslan, Ahmad Ibn. Matnu al-Zubad. Surabaya: alHidayah, t.th.

Sanjaya, Wina. Pembelajaran dalam Implementasi Kurikulum Berbasis Kompetensi (KBK). Jakarta: Kencana Prenada Media Group, 2011. 
Sardiman. Interaksi \& Motivasi Belajar Mengajar. Jakarta: PT. RajaGrafindo Persada, 2014.

Suparlan. Guru sebagai Profesi. Yogyakarta: Hikayat Publishing, 2006.

Uno, Hamzah B. Teori Motivasi dan Pengukurannya. Jakarta: Bumi Aksara, 2011.

Uno, Hamzah B. Teori Motivasi dan Pengukurannya. Jakarta: Bumi Aksara, 2011.

Zahroh, Aminatul. Membangun Kualitas Pembelajaran Melalui Dimensi Profesionalisme Guru. Bandung: CV. Yrama Widya. 